\title{
Antimicrobial susceptibility profiles among bacterial isolates from Nairobi River Water in Nairobi County, Kenya
}

Edinah Song'oro ${ }^{1,2^{*}}$, Andrew Nyerere ${ }^{2}$, Gabriel Magoma ${ }^{1,2}$ and Revathi Gunturu ${ }^{3}$

*Correspondence: edinahsong@gmail.com

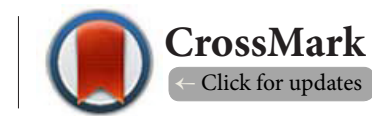

'Pan African University Institute for Basic Sciences Technology and Innovation (PAUSTI), Kenya.

2Jomo Kenyatta University of Agriculture and Technology (JKUAT), Kenya.

${ }^{3}$ The Aga Khan University Hospital, Nairobi (AKUH), Kenya.

\begin{abstract}
Rivers can act as reservoirs of highly resistant strains and help the dissemination of pathogenic strains to animals and humans using water. This study aimed to determine the antimicrobial susceptibility patterns among bacterial isolates from Nairobi River water, Kenya. A total of 18 water samples were collected from three different sampling points along Nairobi River during wet and dry seasons. We employed standard microbiological methods to isolate and identify bacteriafrom these selected sites. Escherichia, Klebsiella, Yersinia, Pseudomonas, Proteus vulgaris, Serratia and Shigella recorded the highest occurrence along the selected sites of Nairobi River. Drug sensitivity using the Disc diffusion method showed that Ceftazidime, Ampicillin, Cefotaxime, Amoxicillin and Cefepime had the highest levels of inactivity ranging from $(61.5 \%$ to $82 \%),(56.3 \%$ to $76.9 \%),(43.6 \%$ to $62.5 \%),(59.4 \%$ to $61.5 \%)$, and $(33.3 \%$ to $44 \%)$ and most susceptible to Levofloxacin (97.4\%), Ciprofloxacin (93\%) and Amoxy/clav (87.5\%). Members of Serratia,Shigella, Escherichia, and Salmonella showed the highest level of extended spectrum beta lactamases (ESBLs) production at $9.8 \%, 9.8 \%, 7.8 \%$, and $7.8 \%$. The sites with human industrial and agricultural zone activities had strains that were more resistant than isolates obtained from the other sites of the river with minimum human activities. The study concludes that, Nairobi River bear heavy burdens of potentially virulent resistant bacterial strains that may form major public health hazards to humans and animal's health. Therefore, there is need to educate people on the use of appropriate protective materials and communities along the Nairobi River.
\end{abstract}

Keywords: Antibiotics, resistance, extended Spectrum Beta Lactamases (ESBLs) and Nairobi River

\section{Introduction}

The release of antimicrobial resistant bacteria and genes originating from human and animal waste to the natural environment is a global problem that has serious effects on public health. Urban rivers in rapidly developing regions are often severely impacted by uncontrolled population growth and lagging infrastructure development $[\mathbf{1 , 2}]$. As such, riverine pollution is a serious and growing public health challenge with antibiotic resistance genes regardedas a critical emerging contaminant $[3,4]$. Aquatic ecosystems are ideal environments for diverse antibiotic resistance genes(ARGs) $[3,5]$ with high levels of ARGs detected in urban rivers [6-8]. The occurrence and dissemination of ARGs in urban river systems have increasingly become a crucial issue with water quality and human health because of the widespread and intensive use of surface waters [9-11]. Found that human activities strongly impact natural antibiotic resistance in the environment.

Natural environments such rivers can serve both as a natural reservoir of antibiotic resistance and a channel for the spread of pathogenic resistance traits of public concern [12]. Aquatic bodies, including rivers and streams receive effluent from waste water treatment plants, runoff from agricultural activity, and 
Songoro et al. Microbiology Discovery 2019,

other human inputs and influences that may raise natural background levels of antibiotic resistance genes and inspire theirtransfer into pathogens for the propagation of antibiotic resistant pathogens and clinical ARGs of concern [12].

Discharge from wastewater treatment plants, industry, hospitals and pig farms, for example, will all eventually reach some water source $[13,14]$. In rivers, the concentration of pollutants in sediments gradually decreases downstream of a source due to hydraulic characteristics [15]. The presence of ARGs in river environment may pose a potential risk to public health, as river water is often used for irrigation, recreation and also used as a source of drinking water. Riverine ARGs and antibiotic resistance bacteria could spread into drinking water and threaten public health via food chain $[16,17]$. Rivers seem to have received most attention among aquatic environments, likely due to their rapid trans- port of antibiotics and ARGs and the obvious identification of pollution sources and landscapes in different reaches $[8,18]$.

Nairobi River is a subset of Ngong River, which flows through the city and serves as a source of water for irrigation by urban farmers before discharges into Athi River. It frequently gets overflowed during rainy seasons and causes floods that brings heavy loses to the local community. Nairobi River has become a destiny to discharge draining water and industrial waste without prior treatment which has become a house to pathogenic bacteria. In the past decades, there have been hundreds of chemical plants and thousands of animal feedlots adjacent to the river's bank. The liquid effluents from chemical plants and animal feedlots are commonly discharged into the Nairobi River. Therefore, ARGs in the Nairobi River may be significantly promoted by anthropogenic activities. Furthermore, ARGs in the Nairobi River may be accessible by humans, since the water from the river is usually used for irrigation and recreation. Hence there is need to know the level of contaminating organism and antimicrobial susceptibility patterns that are responsible for causing infections in the surrounding population.

\section{Materials and Methodology}

\section{Study area and study design}

This study was conducted in Nairobi County, Kenya. Water samples were collected from three different points along Nairobi River using a cross-sectional study design. The systematic sampling technique was used to collect the samples this study area. The samples were collected from March to October 2018.

\section{Nairobi river}

Nairobi River is a river flowing through the Kenyan capital Nairobi. It is the main river of the Nairobi river basin, a complex of several parallel streams flowing eastwards. All of the Nairobi basin Rivers join east of Nairobi and meet the Athi River, eventually flowing to the Indian Ocean. These rivers are mostly narrow and highly polluted with unregulated wastes [19] and its one of the possible hotspot for propagation of resistant genes in the natural environment hence there is need to determine the presence of these resistant genes in Nairobi River (Figure 1 and Table 1).

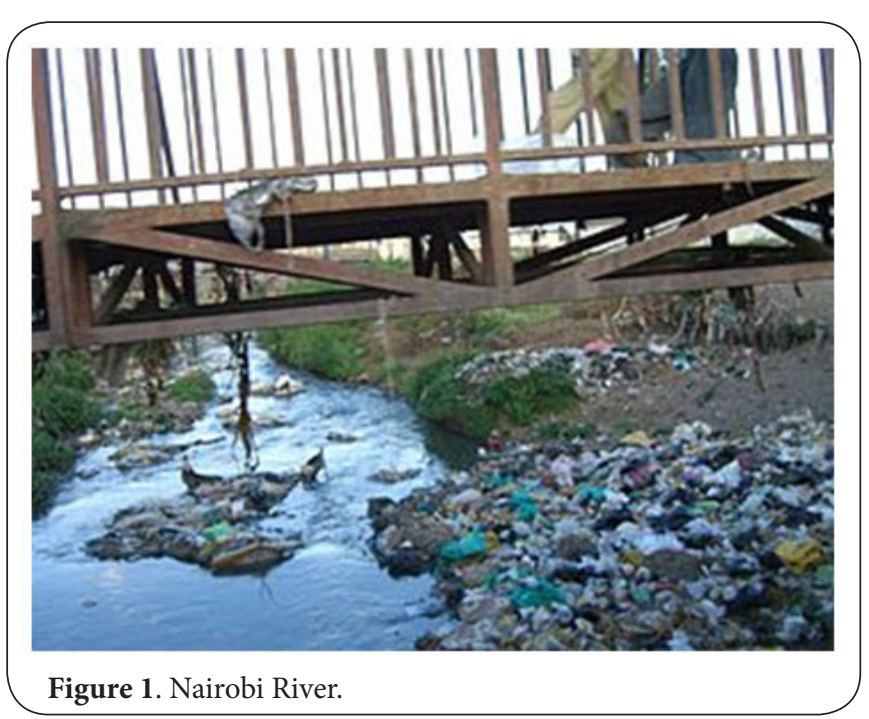

Table 1. Activities on different sites where water was sampled.

\begin{tabular}{ll}
\hline Sites & Activities \\
\hline Site 1 & $\begin{array}{l}\text { Water used for flower farming, construction of roads, } \\
\text { informal settlement }\end{array}$ \\
\hline Site 2 & $\begin{array}{l}\text { Industrial zone, water used for bathing, used for washing } \\
\text { clothes, formal and informal settlement, garage zone, } \\
\text { Livestock watering, dumping along the river }\end{array}$ \\
\hline Site 3 & $\begin{array}{l}\text { Formal settlement, water used for watering flowers, used } \\
\text { for watering crops, livestock watering, next to sewage, } \\
\text { dumping along river }\end{array}$ \\
\hline
\end{tabular}

\section{Sampling points}

The sampling points were selected based on prevailing human activities such as washing, drinking points for livestock, points where residents fetch water to irrigate their crops, and points heavily contaminated with industrial effluent, (Its geographical coordinates are $1^{\circ} 16^{\prime} 7.20^{\prime \prime}$ South, $36^{\circ} 48^{\prime} 21.59^{\prime \prime}$ East, $1^{\circ} 17^{\prime}$ South, $36^{\circ} 49^{\prime}$ East, and the last point $1^{\circ} 20^{\prime} 1.4^{\prime \prime}$ South, $36^{\circ} 55^{\prime} 37.59^{\prime \prime}$ East).

\section{Sampling of raw water}

Water samples were collected from each sampling points between March and October 2018. A total of 3 samples $(500 \mathrm{~mL}$ each) were taken from each site during dry and wet seasons to make a total of 18 water samples. Samples were collected using sterile $500 \mathrm{ml}$ bottles. These bottles were lowered into the water body to a maximum depth of $30 \mathrm{~cm}$ before withdrawal. The samples were transported to Jomo Kenyatta University of Agriculture and Technology Medical Microbiology laboratory in an insulated cool box $\left(4^{\circ} \mathrm{C}\right)$ and processed within $24 \mathrm{hrs}$. 
Songoro et al. Microbiology Discovery 2019,

\section{Bacteria isolation}

Bacteria were isolated by pipetting $0.1 \mathrm{ml}$ onto plates with Nutrient agar media and Tryptic soy agar media (Himedia Lab. Pvt. Mumbai, India), spread with a glass spreader and incubated at $37^{\circ} \mathrm{C}$ for 24 hours. Each colony that appeared on the plate was considered as one colony forming unit [20]. Gram staining was performed to check the morphology of the cells, the bacterial isolates were biochemically characterized by TSI test, motility test, Indole test, Methyl red test, Simmon citrate test and on mannital salt agar [21] the bacteria were classified as described by [22]. Confirmed isolates were then stored at $-80^{\circ} \mathrm{C}$ in tryptic soy broth with $10 \%$ glycerol until used in other experiments.

\section{Antimicrobial susceptibility testing}

Susceptibility tests with thirteen antibiotics were performed using the standard Kirby-Bauer disk diffusion method on Muller Hinton media (HIMedia Lab. Pvt. Mumbai, India). The antimicrobials tested were; amoxicillin $(30 \mu \mathrm{g})$, amoxiclav (30 $\mu \mathrm{g})$, tetracycline $(30 \mu \mathrm{g})$, chloromphenicol $(30 \mu \mathrm{g})$, gentamicin $(10 \mu \mathrm{g})$, ciprofloxacin $(30 \mu \mathrm{g})$, levofloxacin $(10 \mu \mathrm{g})$ ceftazidime $(30 \mu \mathrm{g})$, ampicillin $(10 \mu \mathrm{g})$, cefepime $(30 \mu \mathrm{g})$, cefotaxime $(30 \mu \mathrm{g})$, nitrofrurantoin $(10 \mu \mathrm{g})$, imipenem $(10 \mu \mathrm{g})$, (all HIMedia Lab. Pvt. Mumbai, India). Inoculated plates were incubated at $37^{\circ} \mathrm{C}$ for 18 to $24 \mathrm{~h}$. Measurement of diameters (in millimetres) of clear zones growth inhibition, were compared with the Clinical and Laboratory Standards Institute [23] guidelines. A standard reference strain of E. coli (ATCC 35218) was used as a positive control. The breakpoints used to categorize isolates as resistant, intermediate and susceptible to each antimicrobial agent were those recommended by [23].

\section{Data analysis}

Data were analyzed using the statistical package for social sciences (SPSS 15.0, IBM SPSS, New York, USA). Contingency table analysis was done by a chi-square test. A p-value of less than 0.05 was considered as statistically significant.

Detection of extended-spectrum $\beta$-lactamases (ESBLs) All isolates were tested for ESBLs production using the double disk synergy test following the CLSI 2017 guidelines. In this test, disks of third generation cephalosporin and amoxicillin/ clavulanic acid were kept $30 \mathrm{~mm}$ apart, center to center, on inoculated Mueller-Hinton Agar. A clear extension of the edge of the inhibition zone of cephalosporin towards amoxicillin/ clavulanic disk is interpreted as positive for ESBL production $[24,25]$.

\section{Results}

Susceptibility testing was done against four broad categories of antibiotics namely beta lactams, aminoglycosides, fluoroquinolones and nucleic acid inhibitors. The diameter of the inhibition zones was measured and interpreted to resistant (R) or intermediate (I) or sensitive (S) independently according to the CISI 2017 breakpoints for the four categories.

In this study, 13 different types of antibiotic were used to test susceptibility. Different rates of resistance level were recorded to various isolates recovered from three selected sites along the Nairobi River during wet and dry season as shown in the figures below (Figures 2-5).

\section{Extended spectrum beta lactamases}

Various bacterial isolates obtained from different points of Nairobi River were identified as ESBL producers as shown in (Figure 4).

\section{Discussion}

This study showed that areas with human, animal, agricultural or industrial activities had significantly higher resistant isolates than those with minimal activities. Similar results
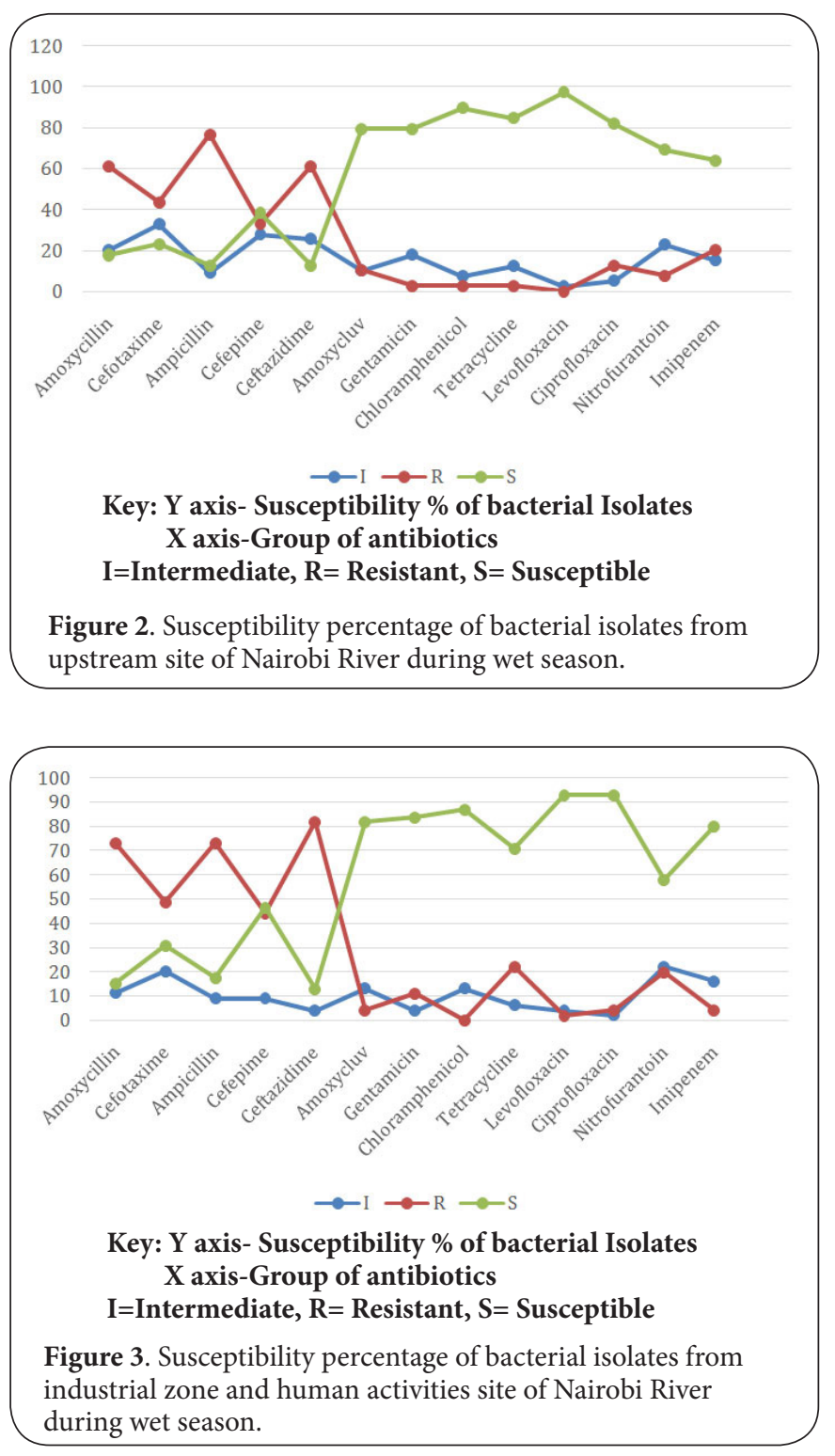

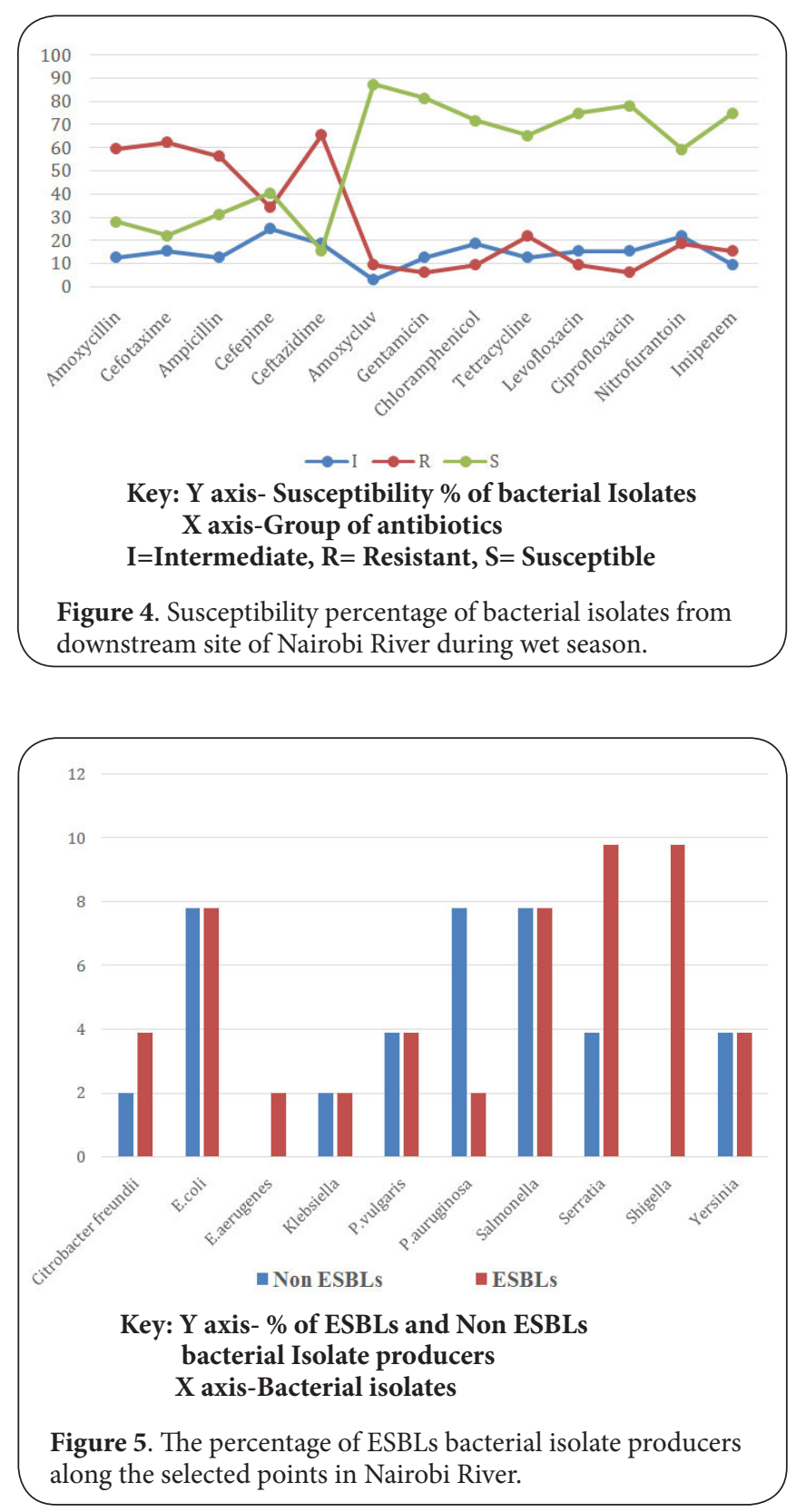

have been obtained in a study conducted in Germany where microbial contamination of water passing through megacities was assessed [26]. Downstream from this area, the number of coliforms declined compared to other sites. As expected, these results showed that water near the sewerage plant was more polluted. This observation indicates possible inefficiencies of the treatment plant. Isolates in dry season were higher than the wet season. These observations differed from those obtained in previous similar studies [27].

The current study also reported high number of resistant bacteria especially for ampicillin, amoxicillin, ceftazidime, cefotaxime, cefepime. These results are close to those published in related studies conducted in [27]. This is a public health concern because increase in resistant bacteria may complicate treatment of infections arising from such strains. We also observed resistance to third generation cephalosporins such as cefotaxime, ceftazidime and to cefepime. These antibiotics are used in treating complicated systemic bacterial infections and therefore, their potency is of immense clinical value [28]. Similar results have been reported in related studies in Turkey, United Kingdom and in China [29,30]. $\beta$-lactams make up to $40 \%$ of the prescribed antimicrobials in an outpatient setting with cephalosporins making up to a total of $14 \%$ of prescriptions in same setting [31] which can mean that resistance to these antibiotics is worrying especially if strains exhibiting resistance to these agents have found their way into the environment.

Presence of highly resistant strains in the water system could be interpreted to mean that Nairobi River is a significant reservoir for pathogenic strains. Related studies conducted in China and Oregon have identified similar river systems as a significant risk factors for highly pathogenic strains [32-34]. Other studies have similarly identified highly resistant strains from river sections polluted with industrial effluent [35-37]. Similar to our findings, a related study showed that high resistant strains are more common from water ways contaminated with runoffs from land occupied by animal and human, and those with urban and industrial sewerage [38]. From the study, Nairobi River water was found to be polluted with high levels of pathogenic bacteria and the water may therefore be unfit for human use. There is a need for better waste management in Nairobi River and public sensitization on ways to treat water as to make it safe for use.

\section{Conclusion}

Nairobi River is highly contaminated with pathogenic microbes. The ability of isolates to be highly resistant to ceftazidime, ampicillin, cefotaxime, amoxicillin and cefepime which are used in treatment of gram negative infections is a public health concern. Therefore, much focus should be placed to study aquatic microbial environment as much as clinical environment. This willbe useful in knowing the pattern of resistant microbes in the environment. This will be important in developing surveillance systems to assess the extent of resistance in aquatic environment in Kenya.

\section{Competing interests}

The authors declare that they have no competing interests.

Authors' contributions

\begin{tabular}{|l|c|c|c|c|}
\hline Authors' contributions & ES & AN & GM & RG \\
\hline Research concept and design & $\checkmark$ & $\checkmark$ & $\checkmark$ & $\checkmark$ \\
\hline Collection and/or assembly of data & $\checkmark$ & -- & -- & -- \\
\hline Data analysis and interpretation & $\checkmark$ & -- & -- & -- \\
\hline Writing the article & $\checkmark$ & -- & -- & -- \\
\hline Critical revision of the article & $\checkmark$ & $\checkmark$ & $\checkmark$ & $\checkmark$ \\
\hline Final approval of article & $\checkmark$ & $\checkmark$ & $\checkmark$ & $\checkmark$ \\
\hline Statistical analysis & $\checkmark$ & -- & -- & -- \\
\hline
\end{tabular}


Songoro et al. Microbiology Discovery 2019,

http://www.hoajonline.com/journals/pdf/2052-6180-7-1.pdf

doi: $10.7243 / 2052-6180-7-1$

\section{Acknowledgement}

We would like to express our sincere appreciation to Pan Africa University Institute for Basic Science, Technologyand innovation and Mawazo Institute for Women Leading Research in Africa for the research grants without which it would have been impossible to do this work. The financial support is highly acknowledged.

\section{Publication history}

Editors: Antonio Pedro Fonseca, University of Porto, Portugal. Received: 20-Jun-2019 Revised: 20-Jul-2019

Accepted: 23-Jul-2019 Published: 15-Aug-2019

\section{References}

1. Singh G, Vajpayee $P$, Ram $S$ and Shanker R. Environmental reservoirs for enterotoxigenic Escherichia coli in south Asian Gangetic riverine system. Environ Sci Technol. 2010; 44:6475-80. | Article | PubMed

2. Enger KS, Nelson KL, Clasen T, Rose JB and Eisenberg JN. Linking quantitative microbial risk assessment and epidemiological data: informing safe drinking water trials in developing countries. Environ Sci Technol. 2012; 46:5160-7. | Article | PubMed

3. Xu Y, Guo C, Luo Y, Lv J, Zhang Y, Lin $H$, Wang L and Xu J. Occurrence and distribution of antibiotics, antibiotic resistance genes in the urban rivers in Beijing, China. Environ Pollut. 2016; 213:833-840. | Article | PubMed

4. Coutinho FH, Silveira CB, Pinto LH, Salloto GR, Cardoso AM, Martins OB, Vieira RP and Clementino MM. Antibiotic resistance is widespread in urban aquatic environments of Rio de Janeiro, Brazil. Microb Ecol. 2014; 68:441-52. | Article | PubMed

5. Amos GC, Zhang L, Hawkey PM, Gaze WH and Wellington EM. Functional metagenomic analysis reveals rivers are a reservoir for diverse antibiotic resistance genes. Vet Microbiol. 2014; 171:441-7. | Article | PubMed

6. Nakayama T, Tuyet Hoa TT, Harada K, Warisaya M, Asayama M, Hinenoya A, Lee JW, Phu TM, Ueda S, Sumimura Y, Hirata K, Phuong NT and Yamamoto $Y$. Water metagenomic analysis reveals low bacterial diversity and the presence of antimicrobial residues and resistance genes in a river containing wastewater from backyard aquacultures in the Mekong Delta, Vietnam. Environ Pollut. 2017; 222:294-306. | Article I PubMed

7. Ouyang WY, Huang FY, Zhao Y, Li H and Su JQ. Increased levels of antibiotic resistance in urban stream of Jiulongjiang River, China. Appl Microbiol Biotechnol. 2015; 99:5697-707. | Article | PubMed

8. Rodriguez-Mozaz S, Chamorro S, Marti E, Huerta B, Gros M, SanchezMelsio A, Borrego CM, Barcelo D and Balcazar JL. Occurrence of antibiotics and antibiotic resistance genes in hospital and urban wastewaters and their impact on the receiving river. Water Res. 2015; 69:234-242. | Article | PubMed

9. Angebault $C$ and Andremont $A$. Antimicrobial agent exposure and the emergence and spread of resistant microorganisms: issues associated with study design. Eur J Clin Microbiol Infect Dis. 2013; 32:581-95. I Article | PubMed

10. Martinez $\mathrm{JL}$ and Baquero F. Emergence and spread of antibiotic resistance: setting a parameter space. Ups J Med Sci. 2014; 119:68-77. I Article | PubMed Abstract | PubMed FullText

11. Czekalski N, Sigdel R, Birtel J, Matthews B and Burgmann H. Does human activity impact the natural antibiotic resistance background? Abundance of antibiotic resistance genes in 21 Swiss lakes. Environ Int. 2015; 81:45-55. | Article | PubMed

12. Michael I, Rizzo L, McArdell CS, Manaia CM, Merlin C, Schwartz T, Dagot C and Fatta-Kassinos D. Urban wastewater treatment plants as hotspots for the release of antibiotics in the environment: a review. Water Res. 2013; 47:957-95. | Article | PubMed

13. Lavilla Lerma L, Benomar N, Casado Munoz Mdel C, Galvez A and Abriouel H. Antibiotic multiresistance analysis of mesophilic and psychrotrophic Pseudomonas spp. isolated from goat and lamb slaughterhouse surfaces throughout the meat production process. Appl
Environ Microbiol. 2014; 80:6792-806. | Article | PubMed Abstract | PubMed FullText

14. Zhu Y.G., Johnson T.A., Su J.Q., Qiao M., Guo G.X., Stedtfeld R.D., Hashsham S.A and Tiedje J.M. Dirvese and abundant antibiotic resistance genes in chine swine farms. Proc. Natl. Acad., Sci. 2013; 110:3435-3440.

15. Chen $B$, Liang $X$, Huang $X$, Zhang $T$ and Li X. Differentiating anthropogenic impacts on ARGs in the Pearl River Estuary by using suitable gene indicators. Water Res. 2013; 47:2811-20. | Article | PubMed

16. Walsh TR, Weeks J, Livermore DM and Toleman MA. Dissemination of NDM-1 positive bacteria in the New Delhi environment and its implications for human health: an environmental point prevalence study. Lancet Infect Dis. 2011; 11:355-62. I Article | PubMed

17. Jiang L, Hu X, Xu T, Zhang H, Sheng D and Yin D. Prevalence of antibiotic resistance genes and their relationship with antibiotics in the Huangpu River and the drinking water sources, Shanghai, China. Sci Total Environ. 2013; 458-460:267-72. | Article | PubMed

18. Storteboom H, Arabi M, Davis JG, Crimi B and Pruden A. Tracking antibiotic resistance genes in the South Platte River basin using molecular signatures of urban, agricultural, and pristine sources. Environ Sci Technol. 2010; 44:7397-404. | Article | PubMed

19. NdirituG. G., N. N. Gichuki P. Kaur and L. Triest. Characterization of environmental gradients using physico-chemical measurements and diatom densities in Nairobi River, Kenya. Aquatic Ecosystem Health \& Management. 2003; 6:343-354.

20. Nazir N., Mirza J.H., Akhtar N., Bajwa R and Nasin G. Some studies of thermophilic and thermotolerant fungi from Lahore, Pakistan. Mycopath. 2007; 5:95-100.

21. Zaved H.K, Rahman Mizanur M., Rahman Mashir M., Rahman A., Arafat S.M.Y and Rahman M.S. Isolation and characterization of effective bacteria for solid waste degradation for organic manure KMITL Sci. Tech. J. 2008; 8:44-55.

22. Cheesbrough M. District Laboratory Practice in Tropical Countries. Part 2. Tropical Health Technology. Cambridge. 2006. I Article

23. Clinical and laboratory standards institute. Performance standards for antimicrobial susceptibility testing $27^{\text {th }}$ Edition. 2017.

24. Rawat $D$ and Nair D. Extended-spectrum $\beta$-lactamases in Gram Negative Bacteria. Journal of Global Infectious Diseses. 2010; 2:263-274.

25. Jarlier V, Nicolas MH, Fournier G and Philippon A. Extended broadspectrum beta-lactamases conferring transferable resistance to newer beta-lactam agents in Enterobacteriaceae: hospital prevalence and susceptibility patterns. Rev Infect Dis. 1988; 10:867-78. | PubMed

26. Abraham WR. Megacities as sources for pathogenic bacteria in rivers and their fate downstream. Int J Microbiol. 2011; 2011. | Article | PubMed Abstract | PubMed FullText

27. Peris Wambugu, Michael Habtu, Phyllis Impwi, Viviene Matiru and John Kiiru. Antimicrobial susceptibility profiles among Escherichia coli strains isolated from Athi River water in Machakos County, Kenya, Advances in Microbiology. 2015; 5:711-719. | Article

28. Sekowska A, Hryniewicz W, Gniadkowski M, Deptula A, Kusza K and Gospodarek E. Antimicrobial susceptibility of metallo-beta-lactamase positive and negative Klebsiella pneumoniae strains isolated from intensive care unit patients. Pol J Microbiol. 2010; 59:67-9. | Pdf | PubMed

29. Leonard AF, Zhang L, Balfour AJ, Garside R and Gaze WH. Human recreational exposure to antibiotic resistant bacteria in coastal bathing waters. Environ Int. 2015; 82:92-100. | Article | PubMed

30. Zhang $H$, Zhou $Y$, Guo $S$ and Chang W. Multidrug resistance found in extended-spectrum beta-lactamase-producing Enterobacteriaceae from rural water reservoirs in Guantao, China. Front Microbiol. 2015; 6:267. | Article | PubMed Abstract | PubMed FullText

31. Jacobson KL, Cohen SH, Inciardi JF, King JH, Lippert WE, Iglesias T and VanCouwenberghe $\mathrm{CJ}$. The relationship between antecedent antibiotic use and resistance to extended-spectrum cephalosporins in group I beta-lactamase-producing organisms. Clin Infect Dis. 1995; 21:1107-13. | Article | PubMed 
32. Tao R, Ying GG, Su HC, Zhou HW and Sidhu JP. Detection of antibiotic resistance and tetracycline resistance genes in Enterobacteriaceae isolated from the Pearl rivers in South China. Environ Pollut. 2010; 158:2101-9. | Article | PubMed

33. Ali H., Ed B., Bacha K and Ketema T. Bacteriological Quality and Antimicrobial Susceptibility of Some Isolates of Well Waters Used for Drinking in Jimma Town, Southwest Ethiopia. Ethiopian Journal of Education and Sciences. 2013; 6:95-108.

34. Hamelin K, Bruant G, El-Shaarawi A, Hill S, Edge TA, Fairbrother J, Harel J, Maynard C, Masson L and Brousseau R. Occurrence of virulence and antimicrobial resistance genes in Escherichia coli isolates from different aquatic ecosystems within the St. Clair River and Detroit River areas. Appl Environ Microbiol. 2007; 73:477-84. | Article | PubMed Abstract | PubMed FullText

35. Kummerer K. Resistance in the Environment. Chemosphere. 2004; 54:311-320. | Article

36. Lupo A, Coyne $S$ and Berendonk TU. Origin and evolution of antibiotic resistance: the common mechanisms of emergence and spread in water bodies. Front Microbiol. 2012; 3:18. | Article | PubMed Abstract | PubMed FullText

37. Suzuki S and Hoa PT. Distribution of quinolones, sulfonamides, tetracyclines in aquatic environment and antibiotic resistance in indochina. Front Microbiol. 2012; 3:67. | Article | PubMed Abstract | PubMed FullText

38. Armstrong JL, Shigeno DS, Calomiris JJ and Seidler RJ. Antibiotic-resistant bacteria in drinking water. Appl Environ Microbiol. 1981; 42:277-83. | Article | PubMed Abstract | PubMed FullText

\section{Citation:}

Songoro E, Nyerere A, Magoma G and Gunturu R. Antimicrobial susceptibility profiles among bacterial isolates from Nairobi River Water in Nairobi County, Kenya. Microbiol Discov. 2019; 7:1.

http://dx.doi.org/10.7243/2052-6180-7-1 